\title{
The environmental porter hypothesis as a technology adoption problem?
}

Citation for published version (APA):

Kriechel, B., \& Ziesemer, T. H. W. (2005). The environmental porter hypothesis as a technology adoption problem? UNU-MERIT, Maastricht Economic and Social Research and Training Centre on Innovation and Technology. MERIT-Infonomics Research Memorandum Series No. 009

https://doi.org/10.26481/umamer.2005009

Document status and date:

Published: 01/01/2005

DOI:

10.26481/umamer.2005009

Document Version:

Publisher's PDF, also known as Version of record

\section{Please check the document version of this publication:}

- A submitted manuscript is the version of the article upon submission and before peer-review. There can be important differences between the submitted version and the official published version of record.

People interested in the research are advised to contact the author for the final version of the publication, or visit the DOI to the publisher's website.

- The final author version and the galley proof are versions of the publication after peer review.

- The final published version features the final layout of the paper including the volume, issue and page numbers.

Link to publication

\footnotetext{
General rights rights.

- You may freely distribute the URL identifying the publication in the public portal. please follow below link for the End User Agreement:

www.umlib.nl/taverne-license

Take down policy

If you believe that this document breaches copyright please contact us at:

repository@maastrichtuniversity.nl

providing details and we will investigate your claim.
}

Copyright and moral rights for the publications made accessible in the public portal are retained by the authors and/or other copyright owners and it is a condition of accessing publications that users recognise and abide by the legal requirements associated with these

- Users may download and print one copy of any publication from the public portal for the purpose of private study or research.

- You may not further distribute the material or use it for any profit-making activity or commercial gain

If the publication is distributed under the terms of Article $25 \mathrm{fa}$ of the Dutch Copyright Act, indicated by the "Taverne" license above, 


\section{MERIT-Infonomics Research Memorandum series}

The Environmental Porter Hypothesis as a Technology Adoption Problem?

Ben Kriechel \& Thomas Ziesemer

2005-009

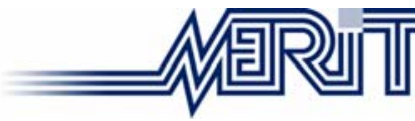

MERIT - Maastricht Economic Research Institute on Innovation and Technology

PO Box 616

6200 MD Maastricht

The Netherlands

T: +31 433883875

F: +31433884905

http://www.merit.unimaas.nl e-mail:secr-merit@merit.unimaas.nl

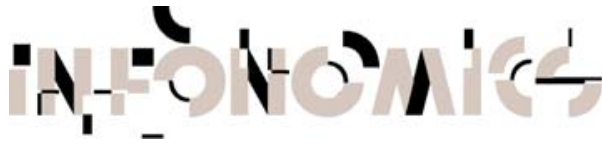

International Institute of Infonomics

c/o Maastricht University PO Box 616

6200 MD Maastricht

The Netherlands

T: +31 433883875

F: +31 453884905

http://www.infonomics.nl e-mail: secr@infonomics.nl 


\title{
The Environmental Porter Hypothesis as a Technology Adoption Problem?*
}

\author{
Ben Kriechel \& Thomas Ziesemer
}

January 2005

\author{
Maastricht University \\ Maastricht University \\ ROA \\ MERIT \\ P.O. Box 616 \\ 6200 MD Maastricht \\ the Netherlands \\ Phone: $++31-43-3883287$ \\ Fax: $++31-43-3884914$ \\ $<$ Ben.Kriechel@roa.unimaas.nl>
}

\begin{abstract}
The Porter Hypothesis postulates that the costs of compliance with environmental standards may be offset by adoption of innovations they trigger. We model this hypothesis using a game of timing of technology adoption. We show that times of adoption are earlier the higher the non-adoption tax. The environmental tax turns the preemption game with low profits into a game with credible precommitment yielding high profits (pro-Porter). If there is a precommitment game without environmental taxes, the introduction of a tax leads to lower profits (anti-Porter).
\end{abstract}

Keywords: Environmental Policy, Strategic Trade Theory,

Technology Adoption, Porter Hypothesis

JEL: $\quad$ Q2, F1, H7, O3

\footnotetext{
${ }^{*}$ We would like two anonymous referees for their valuable comments.
} 


\section{Introduction}

The environmental Porter Hypothesis suggests (see Porter and van der Linde, 1991, 1995a, 1995b) that the costs of compliance with environmental standards may be partially or even fully offset by innovations they trigger. This may even lead to absolute advantages over foreign competitors. In their article geared to policy makers and managers, they state:

"If innovation in response to environmental regulation can be profitable if a company can actually offset the cost of compliance through improving resource productivity — why is regulation necessary at all? [...] $[\mathrm{T}]$ he belief that companies will pick up on profitable opportunities without a regulatory push makes a false assumption about competitive reality namely, that all profitable opportunities for innovation have already been discovered, that all managers have perfect information about them, and that organizational incentives are aligned with innovating." (1995b, p. 127)

Since the general fear of trade economists was one of ecological dumping rather than increased environmental regulation to improve competitiveness, the article was greeted with skepticism. Nevertheless, it led economists to think seriously about the gist of the Porter Hypothesis: Is it possible that firms could gain advantage over their foreign rivals through tougher environmental regulation? While classical trade theory offers no reason to believe in the Porter Hypothesis, imperfect competition models were considered promising to find some theoretical foundations to the case study and anecdotal evidence offered by Porter and van der Linde.

Ulph (1996a) constructs a Brander-Spencer type of strategic trade model with Cournot competition. Firms can invest in technology affecting variable costs but not the accompanying pollution. He shows that the strategic interaction between producers reduces the government's incentive to loosen environmental regulation. He concludes, though, 
that the reduction of pollution with the lowering of the variable costs could change that result. This is the avenue that Simpson and Bradford III (1996) pick up. They model the firms in a similar fashion, with the exception that R\&D not only lowers marginal costs, but also the emission of the pollutant. The government uses effluent taxation to maximize the domestics firm's profits net of the environmental externalities of production. The government is able to force the firm into a Stackelberg-leader position relative to its foreign competitor. For some special cases of specifications and numerical parameter values they are able to construct a strengthening of regulation resulting in a shift of profits from foreign to domestic firms. However, they stress that this is not a general result and it is unlikely that environmental regulation should be used as a policy device to induce industrial advantage. Greaker (2003) models the Porter Hypothesis by assuming that due to the abatement technology the environment is an 'inferior input' in the production process. For some ranges of environmental taxation, this is shown to increase competitiveness. However, the impact on profits remains ambiguous. Feess and Taistra (2001) model a two-period game with Cournot competition. The environmentally friendly technology is assumed to lead to a decrease of unit costs in the second period, however not in a way that reduces overall costs. Policy agencies of the foreign nation are assumed to stochastically imitate the national environmental regulation. Bertrand-type imperfect competition models were introduced in the context of strategic environmental trade policy in the paper by Barrett (1994). In the context of cost saving research Ulph (1996b) shows both for environmental taxation and for environmental standards that firms can benefit from tighter regulation if only the governments act strategically, but firms do not.

Principal-agent models of the Porter Hypothesis are set in the context of organizational inefficiencies. In this model type incentives between principal and agent over the choice of projects are miss-aligned. Environmental regulation helps to re-align the preferences of principal and agent, hence increases the efficiency of the firm (see for example Schmutzler 
(2001) and Klein and Rothfels (1999)). Ambec and Barla (2002) show that, by reducing agency costs, an environmental regulation may enhance pollution-reducing innovation while at the same time increasing firms' private benefit.

Other specifications are e.g. Mohr (2002): he uses a general equilibrium framework with a large number of agents, external economies of scale in production, and discrete changes in technology. As new technologies are modeled with an industry learning curve, firms are stuck in a non-innovating equilibrium, initially. Environmental regulation enforces the adoption of 'new technology', hence allowing for subsequent learning.

Related is Hübner (2001). Using a duopoly model of a patent race, she shows that stricter environmental policy might increase the probability of a sleeping patent instead of encouraging environmental technological progress, but the reversed case is also possible: environmental policy may activate otherwise sleeping patents.

Empirical support for the Hypothesis is based on case study evidence (see Ayres (1994), Porter and van der Linde (1995a)). Ayres (1994) describes the some cases in the utilities and the chemical industry. On the other hand Palmer, Oates and Portney (1995) provide empirical arguments explaining why full offsets are rather unlikely. They base their argument on information provided by entrepreneurs and find no direct evidence for the workings of the Porter Hypothesis. A problem with both of these types of information provision is that the costs of innovation precede the returns and the returns are often stretched out over decades. Jaffe and Palmer (1997) critically evaluate the Porter Hypothesis, they attempt to empirically 'test' the Hypothesis, but find no evidence supporting it. This empirical evaluation is based on the link between the stringency of environmental regulation and $\mathrm{R} \& \mathrm{D}$, but not on adoption.

Our approach differs from earlier approaches to capture the Porter Hypothesis in that we explicitly model the timing choice of both the home and foreign firm based on asymmetries in environmental taxation (regulation). The timing of adoption aspect of the Porter Hypothesis has not been captured in formal theory so far. We try to make a 
first attempt in this paper using the model of technology adoption of Reinganum (1981), Fudenberg and Tirole (1985, 1987).

One point we want to make is that environmental policy may destroy a non-adoption equilibrium. It explains why it may be rational not to adopt, although no opportunities are overlooked. In a static game of technology adoption (Tirole 1988, Chapter 10) with environmental taxation it can be shown that a sufficiently high environmental tax can force firms out of a non-adoption equilibrium. However, this falls short of the Porter Hypothesis which implies a 'competitive' advantage for the nation that introduces the environmental regulation. In the static environment, the increased competitiveness cannot be reached. If one country introduces environmental regulation that forces the 'home' firm out of a static non-adoption equilibrium, the other firm would follow immediately. We use a dynamic model of a game of timing with a case of small environmental taxes turning a preemption game into one of precommitment, therefore, providing a model of the Porter Hypothesis. Thus, the Porter Hypothesis is rejected in as far as the claim is one of increasing overall profits through environmental taxes in general. However, the introduction of a small tax ensures that the home firm would win a preemption game with certainty. This establishes an order of adoption and therefore a precommitment situation which yields higher profits for home than in the preemption game, which would have taken place without the tax. If there is a precommitment game without the taxes, their introduction would reduce profits.

\section{Environmental taxes in a game of timing}

In static models of technology adoption firms either both adopt or not at all even if only one country raises a tax. A less extreme distinction can be considered. Reinganum (1981) and the extension by Fudenberg and Tirole (1985) provide such a model where firms either adopt earlier or later. We apply the model to the case of environmental regulation in the spirit of the Porter Hypothesis. This allows to theoretically evaluate 
the hypothesis, as we allow for dynamic effects which are crucial in the argumentation leading towards an increased competitiveness.

Here we restate their model for the case of two firms and introduce an environmental non-adoption tax, $\tau .{ }^{1}$ We show that all times of adoption — preemption, following and joint late adoption — are earlier the higher the adoption tax. Moreover, an environmental tax ensures a precommitment position for the domestic firm. But it decreases profits when increased further. A low environmental tax ensures a preemptive position of the domestic firm, establishes an order of adoption, and therefore leads also to a precommitment associated with higher profit, for the home firm.

\subsection{Games of Timing: National Case}

Let $\pi_{0}(0)-\tau$ denote after-tax profits of a firm if no firm has yet adopted. $\pi_{0}(1)-\tau$ denotes after-tax profits of a firm if only the other firm has adopted. $\pi_{1}(1)$ is the profit of a firm which has adopted but the other firm has not. $\pi_{1}(2)$ is the profit of a firm if both have adopted. ${ }^{2}$

There is a cost $c(t)$ associated with adoption, where $c$ is a function of time such that early adoption is more costly $\left(c^{\prime}<0\right) .{ }^{3}$ Using index 2 for the firm that is second to adopt, the follower, and index 1 for the leader, the value of the firms with adoption times $T_{1}$ and $T_{2}$ can be written as follows (the first T on the LHS denotes the firms own adoption time, the second the other firms adoption time):

$$
V^{1}\left(T_{1}, T_{2}\right)=\int_{0}^{T_{1}}\left[\pi_{0}(0)-\tau\right] e^{-r t} d t+\int_{T_{1}}^{T_{2}} \pi_{1}(1) e^{-r t} d t+\int_{T_{2}}^{\infty}\left[\pi_{1}(2)\right] e^{-r t} d t-c\left(T_{1}\right)
$$

\footnotetext{
${ }^{1} \tau$ could also be introduced by using country specific cost functions, however our purposes treating it as a separate "cost" serves our purpose best.

${ }^{2}$ The number in brackets is the number of firms that has adopted: 0,1 , or 2 . The lower index $1(0)$ indicates that a firm has (not) adopted.

${ }^{3}$ The cost of adoption, $c(t)$, is defined to be the present value of adopting the new technology at time $t$.
} 
$V^{2}\left(T_{2}, T_{1}\right)=\int_{0}^{T_{1}}\left[\pi_{0}(0)-\tau\right] e^{-r t} d t+\int_{T_{1}}^{T_{2}}\left[\pi_{0}(1)-\tau\right] e^{-r t} d t+\int_{T_{2}}^{\infty} \pi_{1}(2) e^{-r t} d t-c\left(T_{2}\right)$

Firms only differ in two aspects. First, in the second phase firm 1 has adopted and firm 2 has not. Second, the present value of the cost of adoption, $c$, at different points in time are different. Assumptions made on the magnitude of the profit and cost items are the following:

1. There are decreasing returns in the rank of adoption: $\pi_{1}(1)>\pi_{1}(2)$.

2. The difference in profits from adoption, at time zero, is not larger than the decrease in the costs of adopting while waiting: $\pi_{1}(1)-\left[\pi_{0}(1)-\tau\right] \leq-c^{\prime}(0)$ for all $\tau \geq 0$. Therefore immediate adoption is not profitable unless the equality part of the equation holds.

3. Second adoption always becomes profitable after some time: $\inf _{t}\left\{c(t) e^{r t}\right\}<\left\{\pi_{1}(2)-\left[\pi_{0}(1)-\tau\right]\right\} / r$ for all $\tau \geq 0$.

4. Current costs of adoption are falling but decreasingly so: for all $t,\left(c(t) e^{r t}\right)^{\prime}<0,\left(c(t) e^{r t}\right)^{\prime \prime}>0$.

In the national case both firms operate under non-adoption tax. We will develop the optimal timing of adoption in the case of a national competition first, i.e. where both firms are faced with the same environmental regulation and taxation. In the next subsection this will be changed to the international case in which only the home firm is faced with environmental taxation. The derivations of the optimal timings can be applied to the international case by setting the the foreign firm's tax equal to zero.

Precommitment allows a firm to commit to being either follower or leader. However in order for precommitment to matter it has to be credible. We will argue below that 
the environmental tax will eventually allow the firm to credibly precommit. ${ }^{4}$ Given precommitment on the order of adoption, the optimal adoption time for the leader, $T_{1}$, can be found from the first-order condition

$$
d V^{1} / d T_{1}=\left[\pi_{0}(0)-\tau\right] e^{-r T_{1}}-\pi_{1}(1) e^{-r T_{1}}-c^{\prime}\left(T_{1}\right)=0
$$

The optimal adoption time for the follower in case of a precommitment can be found from the first-order condition

$$
d V^{2} / d T_{2}=\left[\pi_{0}(1)-\tau\right] e^{-r T_{2}}-\pi_{1}(2) e^{-r T_{2}}-c^{\prime}\left(T_{2}\right)=0 .
$$

If the leader has already adopted, the second of the two equations determines the followers optimal time, $T_{2}^{*}$. Note that this is the optimal timing for the follower with and without precommitment. It allows us to calculate the impact of the environmental tax on the followers optimal adoption time:

$$
\frac{d T_{2}^{*}}{d \tau}=-\frac{-e^{-r T_{2}}}{\left[\pi_{0}(1)-\tau\right](-r) e^{-r T_{2}}+r \pi_{1}(2) e^{-r T_{2}}-c^{\prime \prime}\left(T_{2}\right)}=-\frac{-e^{-r T_{2}}}{-r c^{\prime}\left(T_{2}\right)-c^{\prime \prime}\left(T_{2}\right)}<0
$$

The second equation has been obtained by insertion of $c^{\prime}$ from equation (2.2). Assumption (4) implies that the denominator, which is also the second-order condition of equation (2.2), has a negative sign.

The dependence of timing of the leader upon the environmental tax can be derived in a similar fashion:

\footnotetext{
${ }^{4}$ See propositions 2.6 and 2.8 .
} 


$$
\frac{d T_{1}^{*}}{d \tau}=-\frac{-e^{-r T_{1}}}{\left[\pi_{0}(0)-\tau\right](-r) e^{-r T_{1}}+r \pi_{1}(1) e^{-r T_{1}}-c^{\prime \prime}\left(T_{1}\right)}=-\frac{-e^{-r T_{1}}}{-r c^{\prime}\left(T_{1}\right)-c^{\prime \prime}\left(T_{1}\right)}<0
$$

This leads us to the following proposition:

Proposition 2.1 The leader and the follower adopt earlier under precommitment if the environmental tax is larger.

If there is no precommitment on the order of adoption, firms may be interested in preemption. The timing of preemption can be found as follows. The leader's payoff if she succeeds in preempting at time $t$ is

$$
L(t)=\left\{\begin{array}{c}
V\left(t, T_{2}^{*}\right) \text { if } t<T_{2}^{*} \\
V(t, t) \text { if } t \geq T_{2}^{*}
\end{array}\right.
$$

The followers payoff if he is preempted at time $t$ is:

$$
F(t)=\left\{\begin{array}{c}
V\left(T_{2}^{*}, t\right) \text { if } t<T_{2}^{*} \\
V(t, t) \text { if } t \geq T_{2}^{*}
\end{array}\right.
$$

If both firms adopt together the payoff for each firm is $M(T)=V(t, t)$.

If $t<T_{2}^{*}, L(t)>M(t)$ and $F(t)>M(t)$. Using the above definitions as in equations (2.1) and (2.2) one finds that

$$
\begin{gathered}
{[L(t)-F(t)]^{\prime}=-\pi_{1}(1) e^{-r T_{1}}-c^{\prime}\left(T_{1}\right)+\left[\pi_{0}(1)-\tau\right] e^{-r T_{1}}=0} \\
{[L(t)-F(t)]^{\prime \prime}=-r c^{\prime}-c^{\prime \prime}<0}
\end{gathered}
$$

because of assumption (4). As $L(t)-F(t)$ has a maximum, each firm would like to 
preempt the other. As in Fudenberg and Tirole (1985) , $L(0)<F(0)$ from assumption (2) and $L\left(T_{2}^{*}\right)=F\left(T_{2}^{*}\right)$ from the definitions of $L$ and $F$ and $L\left(T_{1}^{*}\right)>F\left(T_{1}^{*}\right)$ from $V^{1}\left(T_{1}^{*}, T_{2}^{*}\right)>V^{2}\left(T_{2}^{*}, T_{1}^{*}\right)$ under precommitment. Together with the monotonicity of the value functions this information implies that there must be a point in time, $T_{1}$, at which $L\left(T_{1}\right)=F\left(T_{1}\right)$ (cf. Fudenberg and Tirole, 1985, p. 386). This is the first profitable point in time for preemption. Equating the values of the firms, $V^{1,2}$, for this point in time yields

$$
L\left(T_{1}\right)-F\left(T_{1}\right)=\int_{T_{1}}^{T_{2}} \pi_{1}(1) e^{-r t} d t-c\left(T_{1}\right)-\left\{\int_{T_{1}}^{T_{2}}\left[\pi_{0}(1)-\tau\right] e^{-r t} d t-c\left(T_{2}\right)\right\}=0
$$

Proposition 2.2 Under preemption, the timing of preemptive adoption will be earlier if the environmental tax is higher.

This follows from equation (2.7) which implies:

$$
\frac{d T_{1}}{d \tau}=-\frac{\int_{T_{1}}^{T_{2}} e^{-r t} d t}{-\pi_{1}(1) e^{-r T_{1}}+\left[\pi_{0}(1)-\tau\right] e^{-r T_{1}}-c^{\prime}\left(T_{1}\right)}<0 .
$$

Now suppose that there is joint late adoption and therefore $M=V^{1}=V^{2}$. Insertion of the value functions given above for $T_{1}=T_{2}$ yields

$$
M=V^{1,2}\left(T_{2}, T_{1}\right)=\int_{0}^{T_{1}}\left[\pi_{0}(0)-\tau\right] e^{-r t} d t+\int_{T_{2}}^{\infty} \pi_{1}(2) e^{-r t} d t-c\left(T_{2}\right)
$$

The optimal joint adoption time is found by maximization of $M$ with respect to $T=$ $T_{1}=T_{2}$. The first order condition is

$$
\frac{d M}{d T}=\left[\pi_{0}(0)-\tau\right] e^{-r T}-\pi_{1}(2) e^{-r T}-c^{\prime}(T)=0
$$

From this we can calculate the impact of an increase in the environmental tax on the timing of joint adoption: 
Table 1: Payoff in the game of timing

\begin{tabular}{|cc|cc|}
\hline \multirow{2}{*}{} & & \multicolumn{2}{|c|}{ Foreign } \\
\cline { 3 - 4 } & lead & follow \\
\hline Home & & $\left(L^{h}, L^{f}\right)$ & $\left(L^{h}, F^{f}\right)$ \\
& follow & $\left(F^{h}, L^{f}\right)$ & $\left(F^{h}, F^{f}\right)$ \\
& & & \\
\hline
\end{tabular}

$$
\frac{d T}{d \tau}=-\frac{-e^{-r T}}{-r\left[\pi_{0}(0)-\tau\right] e^{-r T}+r \pi_{1}(2) e^{-r T}-c^{\prime \prime}(T)}<0
$$

Proposition 2.3 Joint late adoption takes place earlier under a higher environmental $\operatorname{tax}$.

\subsection{Games of Timing: International Case}

Now let us suppose that the environmental regulation is one-sided. The firms are located in different countries. Firm 1 is located in 'Home', while firm 2 is located in 'Foreign', competing on a third market without transport costs or tariffs. Foreign does not introduce any environmental regulation.

Table 1 summarizes in general terms the payoff for the firms. Now $\pi_{0}(0)-\tau$ are aftertax profits of the home firm and $\pi_{0}(0)$ for the foreign firm if no firm has yet adopted. $\pi_{0}(1)-\tau$ are after-tax profits of the home firm if only the other firm has adopted and $\pi_{0}(1)$ for the foreign firm. $\pi_{1}(1)$ is the profit of the home firm which has adopted but the other, foreign firm has not. $\pi_{1}(2)$ is the profit of either firm if both have adopted. We use upper indices ' $h$ ' and ' $f$ ' for home and foreign respectively. Let us first examine 
the case in which the home firm is precommitted to be the follower. In this case:

$$
F^{h} \equiv V_{F}^{h}\left(T_{2}^{h}, T_{1}^{f}\right)=\int_{0}^{T_{1}^{f}}\left[\pi_{0}(0)-\tau\right] e^{-r t} d t+\int_{T_{1}^{f}}^{T_{2}^{h}}\left[\pi_{0}(1)-\tau\right] e^{-r t} d t+\int_{T_{2}^{h}}^{\infty} \pi_{1}(2) e^{-r t} d t-c\left(T_{2}^{h}\right)
$$

And for the foreign, precommitted leader, we have:

$$
L^{f} \equiv V_{L}^{f}\left(T_{1}^{f}, T_{2}^{h}\right)=\int_{0}^{T_{1}^{f}} \pi_{0}(0) e^{-r t} d t+\int_{T_{1}^{f}}^{T_{2}^{h}} \pi_{1}(1) e^{-r t} d t+\int_{T_{2}^{h}}^{\infty} \pi_{1}(2) e^{-r t} d t-c\left(T_{1}^{f}\right)
$$

Given that home follows, we can determine the optimal adoption time:

$$
T_{2}^{h}: \frac{\partial V_{F}^{h}}{\partial T_{2}}=\left[\pi_{0}(1)-\tau\right] e^{-r T_{2}^{H}}-\pi_{1}(2) e^{-r T_{2}^{H}}-c^{\prime}\left(T_{2}^{H}\right)=0
$$

We can see that $T_{2}^{H}(r, \tau)$ is independent of $T_{1}$. Further, $\frac{\partial T_{2}^{H}}{\partial \tau}<0$. Hence we can state that:

Proposition 2.4 Home, as the follower, adopts earlier if the environmental tax is larger, decreasing the time that a foreign firm can reap the benefits of early adoption.

Examining the impact of the environmental tax, $\tau$, on the timing of the foreign leader we find:

$$
T_{1}^{f}: \frac{\partial V_{L}^{f}}{\partial T_{1}^{f}}=\pi_{0}(0) e^{-r T_{1}^{f}}-\pi_{1}(1) e^{-r T_{1}^{f}}-c^{\prime}\left(T_{1}^{f}\right)=0
$$

Hence, $T_{1}^{f}$ is independent of $\tau$ and $T_{2}^{H}$. The timing of foreign leadership is not affected by the tax $\tau$ imposed by the home government.

Let us now turn to the case in which home is precommitted leader and foreign is follower:

$$
F^{f} \equiv V_{F}^{f}\left(T_{2}^{f}, T_{1}^{h}\right)=\int_{0}^{T_{1}^{h}} \pi_{0}(0) e^{-r t} d t+\int_{T_{1}^{h}}^{T_{2}^{f}} \pi_{0}(1) e^{-r t} d t+\int_{T_{2}^{f}}^{\infty} \pi_{1}(2) e^{-r t} d t-c\left(T_{2}^{f}\right)
$$




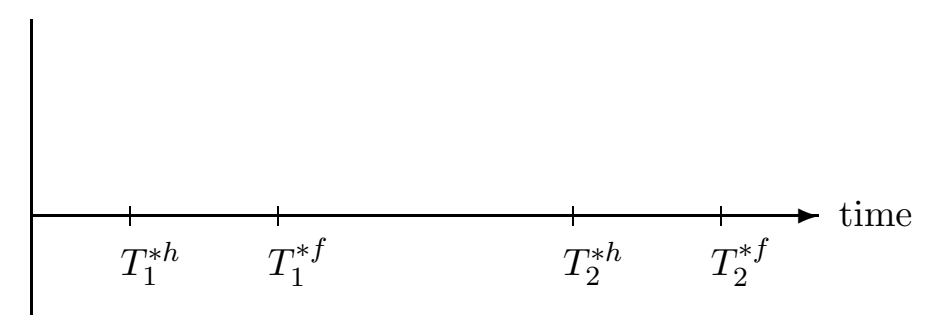

Figure 1: Timing of adoption under precommitment

$$
L^{h} \equiv V_{L}^{h}\left(T_{1}^{h}, T_{2}^{f}\right)=\int_{0}^{T_{1}^{h}}\left[\pi_{0}(0)-\tau\right] e^{-r t} d t+\int_{T_{1}^{h}}^{T_{2}^{f}} \pi_{1}(1) e^{-r t} d t+\int_{T_{2}^{f}}^{\infty} \pi_{1}(2) e^{-r t} d t-c\left(T_{1}^{h}\right)
$$

Again, we can determine the optimal timing of $T_{2}$, given that foreign is committed to follow.

$$
T_{2}^{f}: \frac{\partial V_{F}^{f}}{\partial T_{2}^{f}}=\pi_{0}(1) e^{-r T_{2}^{f}}-\pi_{1}(2) e^{-r T_{2}^{f}}-c^{\prime}\left(T_{2}^{f}\right)=0
$$

Once more, the timing of the foreign firm's adoption, here $T_{2}^{f}$, is independent of $\tau$, but also of the timing of early adoption $T_{1}^{h}$. Further note that, $T_{2}^{H}<T_{2}^{f}$, because $(2.10)$ and (2.14) differ only by $\tau$ in (2.10).

For the timing of home, as the precommitted leader, we get:

$$
T_{1}^{h}: \frac{\partial V_{L}^{h}}{\partial T_{1}^{h}}=\left[\pi_{0}(0)-\tau\right] e^{-r T_{1}^{h}}-\pi_{1}(1) e^{-r T_{1}^{h}}-c^{\prime}\left(T_{1}^{h}\right)=0
$$

Note that the time of adoption is earlier the higher the environmental tax: $\frac{\partial T_{1}^{h}}{\partial \tau}<0$. Home, as a leader, adopts faster than foreign as a leader, i.e. $T_{1}^{h}<T_{1}^{f}$ because of $(2.11)$ and (2.15).

Proposition 2.5 Foreign adopts slower - given that the environmental tax is smaller 
Table 2: Preferences of the Firm

\begin{tabular}{|c|c|c|c|}
\hline & \multicolumn{2}{|c|}{ Foreign } \\
\hline & & lead & follow \\
\hline \multirow{2}{*}{ Home } & lead & $\begin{array}{l}L^{h}-F^{h}>0, \\
L^{f}-F^{f}>0\end{array}$ & $\begin{array}{c}L^{h}-F^{h}>0, \\
L^{f}-F^{f}<0\end{array}$ \\
\hline & follow & $\begin{array}{c}L^{h}-F^{h}<0, \\
L^{f}-F^{f}>0\end{array}$ & $\begin{array}{c}L^{h}-F^{h}<0, \\
L^{f}-F^{f}<0\end{array}$ \\
\hline
\end{tabular}

or equal to zero - than the home firm both as leader and follower

\section{Returns to Leadership and Following}

We have shown above, that - under precommitment - home adopts earlier than the foreign firm, both as a leader and as a follower. Hence, we can order all timing of adoption in the following way: $T_{1}^{h}<T_{1}^{f}<T_{2}^{h}<T_{2}^{f}$, which is also depicted in Figure 1.

We have to make sure, though, that the firms actually want to be leader or follower. In order to examine this we have to examine the difference between leadership returns $L$ and follower returns $F$. Table 2 summarizes the payoff, which will be specified below. Home would like to lead if $L^{h}-F^{h} \geq 0$ and follow otherwise. Subtracting the maximized value of (2.8) from (2.13) yields:

$$
\begin{aligned}
L^{* h}-F^{* h}= & \int_{T_{1}^{* h}(\tau)}^{T_{*}^{* f}}\left[\pi_{1}(1)-\pi_{0}(0)+\tau\right] e^{-r t} d t+\int_{T_{1}^{* f}}^{T^{* h}(\tau)}\left[\pi_{1}(1)-\pi_{0}(1)+\tau\right] e^{-r t} d t \\
& +\int_{T_{2}^{* h}(\tau)}^{T_{2}^{* f}}\left[\pi_{1}(1)-\pi_{1}(2)\right] e^{-r t} d t-\left[c\left(T_{1}^{* h}(\tau)\right)-c\left(T_{2}^{* h}(\tau)\right)\right]
\end{aligned}
$$




\subsubsection{Preemption}

Home will try to preempt as long as $L^{* h}-F^{* h}>0$ and being the leader at the preemption time $T$ yields at least the same revenue as being a follower. At this point the partial differential of equation (2.7) the first profitable time of preemption with respect to the height of the $\operatorname{tax} \tau$ is evaluated:

$$
\left.\frac{\partial T_{1}^{h}}{\partial \tau}\right|_{L^{h}\left(T_{1}^{h}\right)=F^{h}\left(T_{2}^{* h}\right)}
$$

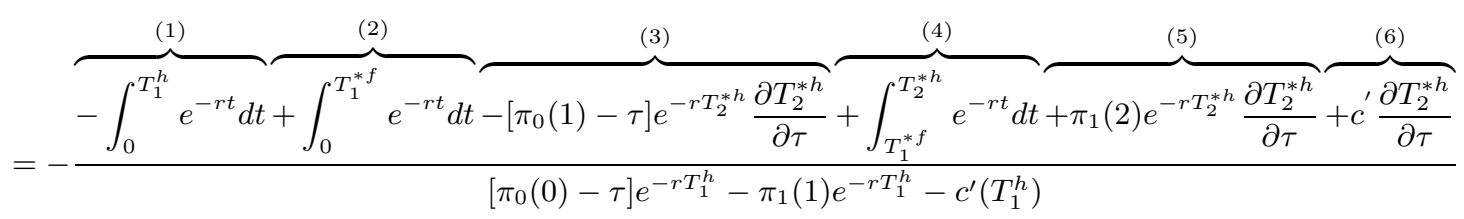

The denominator is greater than zero as $L^{h}-F^{h}=0$ is before (in time) the maximum.

We will evaluate the sign of the numerator by the parts indicated with the brackets above them: The first part (1)

$$
-\left[\frac{1}{-r} e^{-r t}\right]_{0}^{T_{1}^{h}}=-\left[\frac{1}{-r} e^{-r T_{1}^{h}}-\frac{1}{-r}\right]<0 \text { as } T_{1}^{h}>0
$$

has the economic interpretation that the environmental tax reduces the profit of leadership in the first phase, and therefore the first profitable time of adoption is later.

The second part (2) is greater than zero:

$$
\int_{0}^{T_{1}^{* f}} e^{-r t} d t=\left[\frac{1}{-r} e^{-r t}\right]_{0}^{T_{1}^{* f}}=\frac{1}{-r}\left[e^{-r T_{1}^{* f}}-1\right]>0 \text { as } T_{1}^{*}>0
$$

The tax reduces the follower profit in the first phase, the company has an earlier first profitable time of adoption.

The 3rd, 5th and 6th term are all zero, as the Envelope Theorem applies to $F^{* h}$ and therefore $\frac{\partial T_{2}^{h *}}{\partial \tau}$-terms sum to zero and drop out.

The 4 th term ensures that $\frac{\partial T_{1}^{h}}{\partial \tau}<0$, i.e. earlier pre-emption point of time for home with higher environmental taxation. Hence, the taxation insures that the home firm 
always accepts earlier preemption times than foreign, because taxes guarantee lower profits as follower, and will thus win preemption games with certainty (rather than with a 50 percent chance).

Proposition 2.6 A non-adoption tax in one country ensures that the firm in that country can preempt earlier than the firm in the other country. This establishes the order of adoption and therefore the precommitment case becomes relevant, where the home firm get higher profits than in the preemption game.

\subsubsection{Joint late adoption}

Another possibility is that both firms prefer to defer the investment in the new technology, yielding a joint late adoption equilibrium: $M(t)=V(t, t)$.

The value function for foreign will then be:

$$
M^{f}(t)=\int_{0}^{\hat{T}_{1}} \pi_{0}(0) e^{-r t} d t+\int_{\hat{T}_{1}}^{\infty} \pi_{1}(2) e^{-r t} d t-c(t)
$$

The value function for the home firm mirrors that of the foreign firm, with the inclusion of the environmental tax for the non-adoption time.

$$
M^{h}(t)=\int_{0}^{\hat{T}_{1}}\left[\pi_{0}(0)-\tau\right] e^{-r t} d t+\int_{\hat{T}_{1}}^{\infty} \pi_{1}(2) e^{-r t} d t-c(t)
$$

The first order conditions for $c(t)$ are

$$
\begin{aligned}
\frac{\partial M^{f}}{\partial \hat{T}_{1}} & =\pi_{0}(0) e^{-r \hat{T}_{1}}-\pi_{1}(2) e^{-r \hat{T}_{1}}-c^{\prime}\left(\hat{T}_{1}\right)=0 \\
& =\left(\pi_{0}(0)-\pi_{1}(2)\right) e^{-r \hat{T}_{1}}-c^{\prime}\left(\hat{T}_{1}\right)=0 \\
\frac{\partial M^{h}}{\partial \hat{T}_{1}} & =\left(\pi_{0}(0)-\tau-\pi_{1}(2)\right) e^{-r \hat{T}_{1}}-c^{\prime}\left(\hat{T}_{1}\right)=0
\end{aligned}
$$

This environmental tax destroys late adoption, as it leads to earlier adoption than the 
foreign firm, hence destroying the joint late adoption equilibrium.

Proposition 2.7 Even small taxes create a precommitment against (late) joint adoption.

\subsubsection{Returns to leadership}

The change of 'leadership returns' with respect to the environmental tax, $\tau$, for home is evaluated below. Derivation with respect to $T_{1}^{h}$ sum up to zero when the envelop theorem is applied to $L^{h}$ and those with respect to $T_{2}^{h}$ when it is applied to $F^{h}$. Therefore only the direct effects matter.

$$
\begin{aligned}
\frac{\partial\left(L^{h}-F^{h}\right)}{\partial \tau} & =\quad \int_{T_{1}^{h}(\tau)}^{T_{f}^{f}} e^{-r t} d t+\int_{T_{1}^{f}}^{T_{h}^{h}(\tau)} e^{-r t} d t \\
& =\quad\left[-\frac{1}{r} e^{-r t}\right]_{T_{1}^{h}}^{T_{f}^{f}}+\left[-\frac{1}{r} e^{-r t}\right]_{T_{1}^{f}}^{T_{h}^{h}} \\
& =-\frac{1}{r}\left[e^{-r T_{1}^{f}}-e^{-r T_{1}^{h}}\right]-\frac{1}{r}\left[e^{-r T_{2}^{h}}-e^{-r T_{1}^{f}}\right] \\
& =-\frac{1}{r}\left[e^{-r T_{1}^{h}}-e^{-r T_{2}^{h}}\right]>0
\end{aligned}
$$

A higher non-adoption tax increases the desire to lead, because it reduces profits from followership, $F^{h}$, more than from leadership, $L^{h}$. Similarly, the foreign firm would like to lead if $L^{f}-F^{f} \geq 0$.

$$
\begin{aligned}
L^{f}-F^{f}= & \int_{T_{1}^{h}}^{T_{1}^{f}}\left[\pi_{0}(0)-\pi_{0}(1)\right] e^{-r t} d t+\int_{T_{1}^{f}}^{T_{2}^{h}}\left[\pi_{1}(1)-\pi_{0}(1)\right] e^{-r t} d t \\
& +\int_{T_{2}^{h}}^{T_{2}^{f}}\left[\pi_{1}(2)-\pi_{0}(1)\right] e^{-r t} d t-\left[c\left(T_{1}^{f}\right)-c\left(T_{2}^{f}\right)\right]
\end{aligned}
$$

Now the effect of the 'home tax' on foreigns willingness to lead (or follow), is captured in the following derivative:

$$
\frac{\partial\left(L^{f}-F^{f}\right)}{\partial \tau}=-\left[\pi_{0}(0)-\pi_{0}(1)\right] e^{-r T_{1}^{h}} \frac{\partial T_{1}^{h}}{\partial \tau}+\pi_{1}(1) e^{-r T_{2}^{h}} \frac{\partial T_{2}^{h}}{\partial \tau}-\pi_{1}(2) e^{-r T_{2}^{h}} \frac{\partial T_{2}^{h}}{\partial \tau}
$$


Figure 2: Timing of Technology Adoption under Pre-commitment

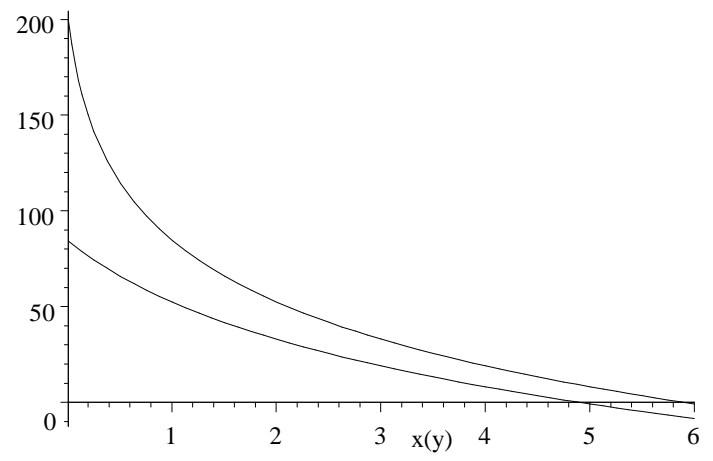

We cannot fully sign the derivative. ${ }^{5}$ Therefore we give a numeric simulation in the next subsection.

\subsection{Simulations}

The cost function in this numerical simulations will be parameterized as $c(t)=100 \cdot e^{-\alpha t}$. The assumption of $c^{\prime}<0$ and $c^{\prime \prime}>0$ are then fulfilled for all economically sensible parameter values of $\alpha \in \mathbb{R}^{+}$. The parameter $\alpha$ can be interpreted as one of technological advancement lowering the cost of adoption over time.

We have parameterized the profits after innovation using an additional parameter $x$ indicating the increase in profits through the new technology, denoting long-run advantage of the new technology. Note that this advantage is lasting even after the follower has also adopted. For the different parameter values that we have tried, refer to Table $3 .^{6}$ In case 3 , we find the possibilities for preemption and precommitment. In the other case there is no case of preemption because the short-run gain is too low. In the simulation that we will discuss extensively in this section, case 3 , we set the interest rate to be $r=0.04$, and the

\footnotetext{
${ }^{5} \mathrm{~A}$ large $\pi_{0}(1)$ makes the desire to lead weaker, because it gives a higher weight to the timing shift effect. But a larger $\pi_{2}(1)$ has opposing effects directly and from equation (2.3).

${ }^{6}$ The parameter values presented in the table give the most relevant variations for this simulation exercise. We have tried other parameter values who confirm the results we present here.
} 
Table 3: Simulation Parameters and Results

\begin{tabular}{c|rrrrrrrl}
\hline Case & $\pi_{0}(1)$ & $\pi_{0}(0)$ & $\pi_{1}(2)$ & $\pi_{1}(1)$ & $\alpha$ & $r$ & $z \cdot c$ & Result \\
\hline 1 & 1.9 & 2 & $2+x$ & $2.2+x$ & 0.2 & 0.04 & $100 c$ & precommit \\
2 & 1.9 & 2 & $2+x$ & $2.2+x$ & 0.1 & 0.04 & $200 c$ & precommit \\
3 & 1.9 & 2 & $2+x$ & $3.1+x$ & 0.1 & 0.04 & $100 c$ & preempt or precommit \\
4 & 1.9 & 2 & $2+x$ & $2.2+x$ & 0.1 & 0.04 & $100 c$ & precommit \\
\hline
\end{tabular}

cost decrease of adopting the new technology over time to be $\alpha=0.1$. The returns gross of adoption costs we assume are $\pi_{0}(1)=1.9, \pi_{0}(0)=2, \leq \pi_{1}(2)=2+x<\pi_{1}(1)=3.1+x$. In words, being a follower decreases the profits by five percent, whereas the (temporary) leader gains more than fifty percent in the short run plus some value $x=\pi_{1}(2)-\pi_{0}(0)$ gross of cost of adoption in the long run. This value of $x$ remains after the follower has caught up and also implemented the new technology. Setting $x$ to zero thus would indicate that - at least in terms of profits - no advantage of adoption would remain.

The timing of technology adoption can be calculated both for given (precommitted) leadership and followership according to equations (2.10, 2.11, 2.14, and 2.15). Figure 2 plots the timing of adoption for various levels of $x$ or $y \equiv x+\tau$ for foreign and home respectively. The inner line plots the timing given a firm's precommitment to leading, the outer line gives the optimal time of adoption given precommitment to follow.

As this figure is based on precommitment, we have to show that firms actually want to be leader or follower. If, for example, both firms would want to lead, a game of preemption will occur in which earlier points of times are chosen than those given in Figure 2. We will deal with preemption further below.

In Figure 3 we plot $L-F$ values for both home and foreign (cf. Equations 2.16 and 2.17) for various levels of $x$ and $y \equiv x+\tau . L-F$ is the profit from leading minus profits from following, hence as long as it is positive, a firm will attempt to be the first to adopt. The figure graphically illustrates this situation for the home and foreign firm. The area in which the $L-F$ area is above zero home would like to lead. Areas that are overlapping between those two figures indicate regions of pre-emption. Note that $x$ has 
Figure 3: Willingness to lead: $L-F$

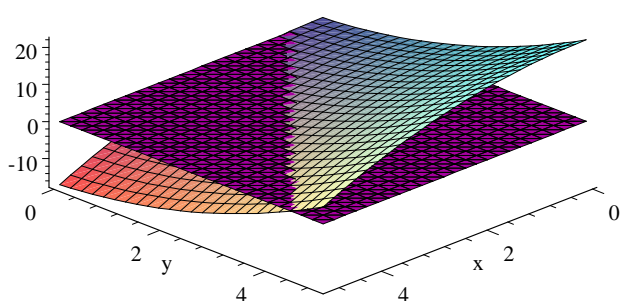

Home

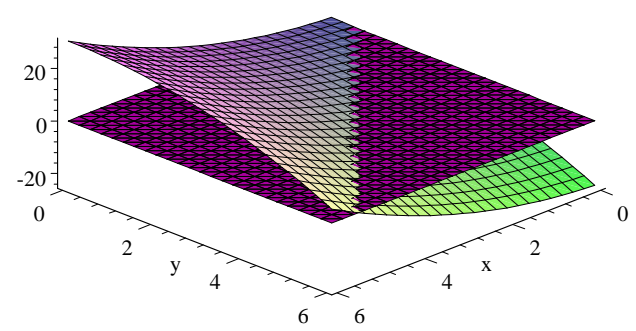

Foreign

the interpretation as above, i.e. continued gain in profits through technology, while $y$ is defined as the sum of $x+\tau$. For the chosen parameter specification and cost functions, the 45 degree line of $x=y$, i.e. no environmental tax, is an overlapping region in which both home and foreign would like to lead. Hence, preemption would take place by each firm with fifty percent chance (Fudenberg and Tirole 1987). However, for large $\tau>0$, i.e. $x<y=x+\tau$ we can see that both firms are pulled out of the preemption area and home will be the leader ( $L-F$ is positive for the home firm) whereas foreign prefers to follow ( $L-F$ is negative for the foreign firm). Only for small values of $x$ and $\tau$ will preemption take place.

Proposition 2.8 If the short-term gain is large enough to allow for a preemption case, low environmental taxes induce a preemption game which is certainly won by the home firm. The foreign firm will not want to play it. The order of adoption being established there will be a precommitment outcome of the game. High non-adoption taxes induce a precommitment for the home firm to be the leader directly.

In Figure 4 the "height" gives the first profitable time $T$ of preemption. Note that the points of time are decreasing for home with the y-axis while they are decreasing for foreign along the x-axis. Preemption should result with low $\tau$ and precommitment with 

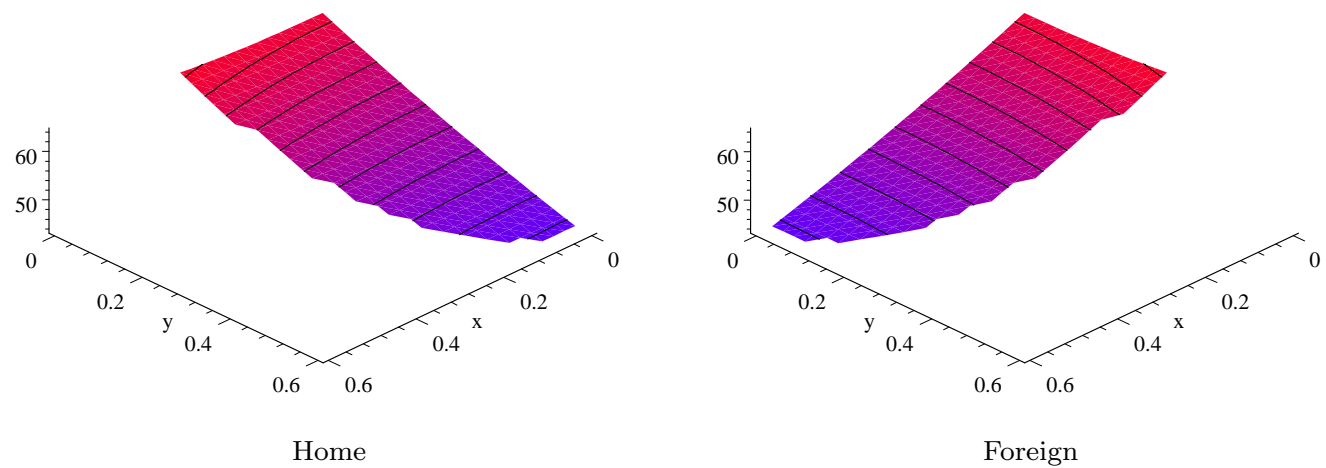

high environmental taxes $\tau$. In the case of a preemption game, the lower $x$ is (along the 45 degree line) and the higher $\tau$ (moving parallel to the y-axis), within the preemption range, the later will be the first profitable point of preemption for the foreign firm. For home, higher environmental taxes lead to earlier profitable points of preemption. Hence, home will have an earlier profitable preemption point of time for any $\tau>0$, therefore, it will preempt just before foreign's first profitable point of preemption (which yields higher profits than home's first profitable point, and is sufficient to be the first one to preempt). We can then calculate the profits of preemption as a function of $x$ and $\tau$. Increasing $\tau$ leads to lower preemption profits. Figure 5 summarizes the profits of home as a function of $x$ and $y=x+\tau$. The left figure gives the profits as a function of $x$ and $y=x+\tau$. Profits are increasing along the 45 degree line and an increase in $\tau$ will lower the profits of the firm. This implies that environmental taxation does not lead to higher profits of the firms in games of preemption. The right part of Figure 5 gives the profits under precommitment: For small values of $x$ (and $\tau$ ) an increase in environmental taxation will lead to lower profits. Under high levels this is reversed. Only in this last case, the Porter Hypothesis would be supported. However, these high values of $y$ imply negative adoption times and therefore have to be excluded, which one can show by cutting off 
Figure 5: Home's Profits for Preemption and Precommitment

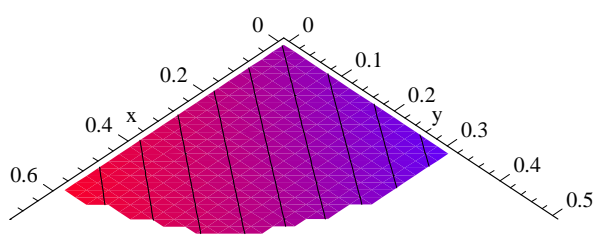

Preemption

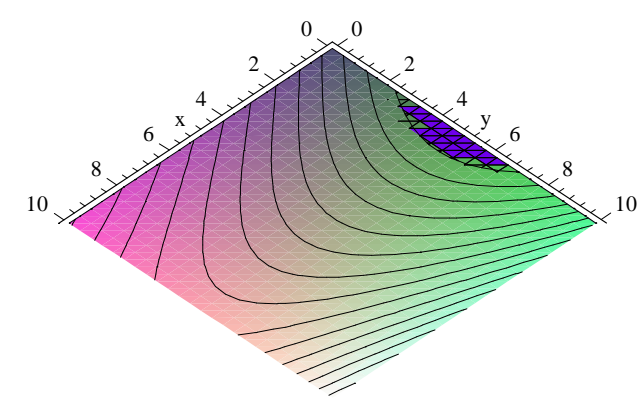

Precommitment

the graph at the value of $y$ at which there is immediate adoption.

Proposition 2.9 Profits under preemption are lower the larger the non-adoption tax and profits under precommitment are lower for higher taxes.

For all other numerical values which do not violate the assumptions of the model we found results that are qualitatively identical.

We have shown in this last section that environmental regulation can be beneficial in the strategic games of timing, to allow the home firm to lead and avoid preemption. One should bear in mind that this numerical example was contrived and is specific to the parameter values at hand. Many other scenarios can be thought might be just as compelling. Nevertheless, we have shown that environmental tax allows for a quicker adoption, and a longer time of 'leadership' under precommitment and a shorter time of followership in general. Profits of the firm, however, are not higher: Higher taxes decrease the profits in the first phase of (3.13), induce a longer second phase $\left(T_{2}^{f}\right.$ is unaffected by $\tau$ ) and a shorter first phase and higher adoption costs. The net effect is negative.

Corollary 2.10 In case of precommitment under no environmental tax, the introduction 
of a tax decreases profits (anti-Porter). In case of a preemption game under no environmental tax, the introduction of a small tax allows the home firm to win the preemption game, and thus establishes an order of adoption. This leads to a precommitment case which assures higher profits of the home firm compared to the preemption game (proPorter).

In essence we have constructed an example of the weak version of the Porter Hypothesis, as firms - maximizing their profits - are pulled out of an equal chance preemption equilibrium in such a way that the firm constrained by the environmental regulation adopts earlier with certainty. Competitiveness in the sense of winning a preemption game is enhanced. Non-environmental as well as environmental welfare is enhanced for consumers of home, as they get higher quality and cleaner products earlier.

\section{Optimal timing}

In order to obtain a welfare function we can enhance the profit functions (2.8), (2.9), (2.12), (2.13) by adding an environmental damage function, $-D$, consumer benefits, $S$, and tax revenues. Tax revenues and payments then drop out. In the simplest case of a process innovation with no change in consumer benefits we then only have to add the environmental damage function. Assuming, again for simplicity, that pollution is only national, then a simple assumption for a damage function is

$$
D_{i}^{j}=\int_{0}^{T_{i}^{j}} d_{0} e^{-r t} d t+\int_{T_{i}^{j}}^{\infty} d_{1} e^{-r t} d t \text { with } i=1,2, j=h, f
$$

depending on whether the country is the home or the foreign country and is adopting first or second. $d_{0}$ is the environmental damage per period before adoption and $d_{1}$ after the adoption. When taking the time derivatives this will augment the functions (2.10), 
(2.11), (2.14), (2.15) (without tax term) by the term

$$
-\left(d_{0} e^{-r T_{i}^{j}}-d_{1} e^{-r T_{i}^{j}}\right)
$$

This term appears where taxes appeared before and have dropped out when canceled against the revenue term. By implication the old and the new equations are the same in the special case where

$$
\tau=d_{0}-d_{1}>0
$$

In this case the tax would be a Pigouvian policy instrument, not taking into account strategic interactions between firms or governments. The effect of taking into account damages then is the same as that of taxes as analyzed above: all adoption times are earlier then without taking into account taxes or damages respectively. In the Cournot literature cited above the tax was reduced in the second stage game between governments because of the strategic interactions. We do not carry out such a second stage game because it is tractable only in a numerical way anyway and probably not something that governments can reasonably be expected to do for every adoption problem. We did show above that a small tax by one government only may be enough to move the preemption position from a 50/50 chance to one of zero to the home firm. However, if the tax is increased further profits fall. On the other hand, a higher tax generates an earlier first-profitable time of adoption and therefore a strategic advantage in a second stage game. This might give an incentive for governments to put their value above the Pigouvian one. If both governments decide to have the same tax in a symmetric game, there is no impact on the first profitable time of adoption. Home must have a slightly larger tax than foreign, other things equal. The foreign tax can be normalized to unity. Therefore we concentrated on Porter's case of a one-sided tax. Our analysis as presented above, however, is not limited to a Pigouvian tax, but rather can have any value. 
Extending the welfare function for consumer benefits in case of delivery to third markets only is slightly more complicated. It would imply, in one of the possible models we could imagine, considering international welfare and therefore the sum of the profit functions for home and foreign. Consumer benefits then are increased twice, first, when the first firm adopts and offers a better quality probably at a higher price and, second, when the second firm adopts and price competition decreases the price of the better variant. The formal treatment then requires adding consumer benefits

$$
S_{i}^{j}=\int_{0}^{T_{1}^{j}} s_{0} e^{-r t} d t+\int_{T_{1}^{j}}^{T_{2}^{j}} s_{1} e^{-r t} d t+\int_{T_{2}^{j}}^{\infty} s_{2} e^{-r t} d t \text { with } j=h, f
$$

to the sum of (2.8) and (2.10) or that of (2.12) and (2.13) using the adequate $j, h$ or $f$, after adding the environmental damage function and dropping the tax terms as above. We leave the exploration of details to the interested reader, noting that it is an international optimum now, obtained as an enhanced joint profit-maximization problem. It can serve only as a benchmark but not as a recommendation for any international institution, because there is no one deciding on technology adoption or cares for consumer benefits in the sense of this model. A second model we could imagine would be one where welfare is defined as national profits plus benefits of customers abroad. Then a consumer benefit function could be written down that is completely symmetric to the damage function above. The tax term $\tau$ would then be replaced by $d_{0}-d_{1}-\left(s_{0}-s_{1}\right)>d_{0}-d_{1}$ in the conditions for optimal timing and the marginal consumer benefit would do the same as a tax or the marginal damage, that is inducing earlier adoption times. ${ }^{7}$

\footnotetext{
${ }^{7} \mathrm{~A}$ complication arises here if a customer switches to the foreign competitor after adoption of the home firm. It is reasonable to assume that this does not decrease the total benefit of the consumers of the home firm.
} 


\section{Conclusion}

Given the prominent role of innovation offsets in the Porter Hypothesis we did prefer to model it using a framework of technology adoption by Fudenberg and Tirole. In the stationary version of the model non-adoption is an equilibrium outcome although firms are profit maximizing.

In our dynamic version of the technology adoption model early adoption is more costly than late adoption. By implication, immediate adoption cannot be expected and an equilibrium with time periods where a new technology is not adopted by profit maximizing firms is a rational outcome.

In the national case, under precommitment on the order of adoption, the leader and the follower adopt earlier if the environmental tax is larger. Under preemption, the timing of preemptive adoption will be earlier if the environmental tax is higher. Joint late adoption takes place earlier under a higher environmental tax.

In the international case, the home country raises a tax but the foreign country does not. Under precommitment on the order of adoption, if home is the follower it adopts earlier if the environmental tax is larger, decreasing the time that a foreign firm can reap the benefits of early adoption. Comparing behavior as follower, foreign adopts slower than home, because in foreign there is no environmental tax by assumption. If there is a preemption game, a non-adoption tax in one country ensures that the firm in that country can preempt earlier than the firm in the other country. The home firm preempts just before the foreign firm would do. The chance of preemption jumps from 50/50 to $100 \%$ for the home country if there is an environmental tax. The case of preemption will exist under a low environmental tax only if the temporary gains of first adoption are high relative to the temporary losses of second adoption.

If home wins the preemption game with certainty thanks to the environmental tax, foreign, foreseeing this, limits itself to following. The resulting game then is one of precommitment. 
Under high non-adoption taxes or low temporary gains and losses there is a precommitment for home to be the leader anyway. Ex-post profits of the home firm are lower under precommitment the larger the tax is. In sum, a tax introduces a reduction in expost profits in a precommitment game (anti-Porter), but also turns a preemption game into one of precommitment, which yields higher profit (pro-Porter).

\section{References}

Ambec, S. and Barla, P.: 2002, A theoretical foundation of the Porter hypothesis, Journal of International Economics 75(3), 355-560.

Ayres, R. U.: 1994, On economic disequilibrium and free lunch, Environmental and Resource Economics 4(5), 435-454.

Barrett, S.: 1994, Strategic environmental policy and international trade, Journal of Public Economics 54(3), 325-338.

Feess, E. and Taistra, G.: 2001, Environmental regulations and managerial myopia, Jahrbücher für Nationalökonomie und Statistik 220(1), 18-31.

Fudenberg, D. and Tirole, J.: 1985, Preemption and rent equalization in the adoption of new technology, Review of Economic Studies 52(3), 383-401.

Fudenberg, D. and Tirole, J.: 1987, Understanding rent dissipation: On the use of game theory in industrial organisation, American Economic Review 77(2), 176-183.

Greaker, M.: 2003, Strategic environmental policy; eco-dumping or a green strategy?, Journal of Environmental Economics and Management 45(3), 692-707.

Hübner, M.: 2001, Sleeping process patents and environmental innovation, Jahrbücher für Nationalökonomie und Statistik 222(6), 706-718.

Jaffe, A. B. and Palmer, K.: 1997, Environmental regulation and innovation: A panel data study, The Review of Economics and Statistics 79(4), 610-619.

Klein, M. and Rothfels, J.: 1999, Can environmental regulation of X-inefficient firms create a "double dividend"?, Technical Report 103, Institut für Wirtschaftsforschung Halle, Halle.

Mohr, R. D.: 2002, Technical change, external economies, and the Porter hypothesis, Journal of Environmental Economics and Management 43(1), 158-168. 
Palmer, K., Oates, W. E. and Portney, P. R.: 1995, Tightening environmental standards: The benefit-cost or the no-cost paradigm, Journal of Economic Perspectives 9(4), 119-132.

Porter, M. E.: 1991, America's green strategy, Scientific American 264(4), 168.

Porter, M. E. and van der Linde, C.: 1995a, Toward a concept of the environmentcompetitiveness relationship, Journal of Economic Perspectives 9(4), 97-118.

Porter, M. and van der Linde, C.: 1995b, Green and competitive: Ending the stalemate, Harvard Business Review 73(5), 120-134.

Reinganum, J. F.: 1981, On the diffusion of new technology: A game theoretic approach, Review of Economic Studies 48(3), 395-405.

Schmutzler, A.: 2001, Environmental regulations and managerial myopia, Environmental and Resource Economics 18, 87-100.

Simpson, D. R. and Bradford III, R. L.: 1996, Taxing variable cost: Environmental regulation as industrial policy, Journal of Environmental Economics and Management 30(3), 282-300.

Tirole, J.: 1988, The Theory of Industrial Organisation, MIT Press.

Ulph, A.: 1996a, Environmental policy and international trade when governments and producers act strategically, Journal of Environmental Economics and Management 30(3), 265-281.

Ulph, A.: 1996b, Strategic environmental policy and international trade - the role of market conduct, in C. Carraro, Y. Katsoulacos and A. Xepapadeas (eds), Environmental Policy and Market Structure, Kluwer Academic Publishers, Dordrecht, pp. 99-127. 